\title{
Kazus (anty)duchowości behawiorysty radykalnego B. F. Skinnera - perspektywa psychobiograficzna
}

\begin{abstract}
Abstrakt
Celem artykułu jest pokazanie, jak wychowanie religijne, którego doświadczył B. F. Skinner, zmieniło jego postrzeganie człowieka i świata, a w ostateczności wpłynęło na porzucenie przez niego wiary i skierowało go na ścieżkę radykalnego behawioryzmu. Analiza dostępnej literatury wykazuje, że różnica w poglądach przeciwników Skinnera (Joseph Wood Krutch, Tomasz Szasz, Ayn Rand) oraz jego sojuszników (Richard Dawkins, Daniel Dennett, Sam Harris) polega na ich odmiennym wychowaniu i złożonych życiowych doświadczeniach. Powiązane z tym przekonania wpłynęły na pojmowanie przez nich duchowości czy wolnej woli.
\end{abstract}

Słowa kluczowe: duchowość, przekonania, wychowanie.

\section{The Case of the Anti-spirituality of the Orthodox Behaviorist B. F. Skinner - A Psychobiographic Perspective}

\begin{abstract}
The purpose of the article is to show how the religious education that B. F. Skinner experienced changed his perception of man and the world, and ultimately influenced his abandonment of faith and directed him onto the path of radical behaviorism. Analysis of the available literature shows that the difference in the views of Skinner's opponents (Joseph Wood Krutch, Tomasz Szasz, Ayn Rand) and his allies (Richard Dawkins, Daniel Dennett, Sam Harris) lies in their different upbringing and complex life experiences. Related beliefs influenced their understanding of spirituality and free will.
\end{abstract}

Keywords: spirituality, beliefs, nurture.

* Uniwersytet Kardynała Stefana Wyszyńskiego w Warszawie.

** Uniwersytet Adama Mickiewicza.

Artykuł otrzymano: 25.05.2020; akceptacja: 4.08.2020. 
Psycholog Burrhus Frederick Skinner - ortodoksyjny behawiorysta - wychował się w amerykańskim środowisku protestanckim. Jego stwierdzenia o konieczności porzucenia wiary w wolną wolę i godność człowieka wzburzały środowisko filozofów już za życia badacza, czyniąc z niego przeciwnika Człowieka Autonomicznego (Rand 1982), mordercę człowieka (Szasz 1974) czy aroganta, który ustawił się na miejscu Boga (Krutch 1953). Skinner porzucił wiarę w Boga już w liceum i wielokrotnie w ciągu całego swojego życia podkreślał, że religia posługuje się mechanizmami warunkowania instrumentalnego, tym samym zwodząc swoich wyznawców. Swoje dzieci wychował jako osoba niewierząca, zostawiając im możliwość wyboru. Pod koniec życia Skinner popełnił krótki artykuł What Religion Means To Me (Skinner 1987). Podkreślał w nim znaczenie determinizmu - to, co się dzieje, po prostu się dzieje i należy to przyjąć bez zastanawiania się nad przyczynami. Strata wiary była dla niego źródłem zmartwień, jednak nauka dała mu spokój i ukształtowała jego najważniejsze wartości, między innymi uczciwość intelektualną. Przyznał, że nie boi się śmierci ani żadnej pośmiertnej kary, ponieważ niczego nie mógłby tam osiągnąć - a jego ludzkie zadanie zostało spełnione - żył. Mimo porzucenia wiary w Boga Skinner nigdy nie porzucił tematu duchowości i wychowania. Niemalże wszystkie dzieła Skinnera odnosiły się do religii, a wśród nich najbardziej krytykowane Walden Two (1948b), Verbal Behavior (1953), Behawioryzm (2013) czy wreszcie Poza wolnościq i godnościq (1978).

Celem niniejszego artykułu jest pokazanie, że częste nawiązywanie do religii w jego pracach mogło mieć związek z rodziną i kulturą, w której Skinner został wychowany. Narzucona przez rodzinę Skinnerów duchowość, a także presja środowiska, w którym dojrzewał Burrhus Frederick, mogła pozbawić go wiary w wolną wolę oraz Boga i ostatecznie skierować go na ścieżkę radykalnego behawioryzmu.

Perspektywa badawcza, która posłużyła do napisania niniejszego artykułu, to psychodynamiczna koncepcja Williama Mariona Runyana dotycząca czynników wpływających na kształtowanie się jednostki, a w szczególności model faz i stanów, który posłużył do badania łańcuchów przyczynowych (Runyan 1992; Pawelec 2002). Jest to koncepcja psychobiograficzna oparta na analizie dokumentów osobistych, dokładniej: metodzie egzemplifikacji, czyli ilustrowaniu przyjętych hipotez przykładami z zebranych dokumentów. Bezpośrednią inspiracją dla niej są badania psychologiczne i psychiatryczne (Runyan 1992). Krytycy metody określają ją jako niesprawdzalną i nieobiektywną (Pawelec 2002), jednak w perspektywie tej nie możemy mówić o prawdzie czy fałszu, ponieważ ta sama osoba może dostarczyć wielu wersji biografii w zależności od kontekstu, czasu i rozmaitych interakcji (Runyan 1992). Dodatkową perspektywą badawczą jest koncepcja Karla Jaspersa dotycząca sytuacji granicznych, czyli poczucia ograniczoności wobec nieuniknionych wydarzeń i ich wpływu na rozwój jednostki (Piszkalski 1978). Zwraca ona uwagę na kontekst sytuacyjny oraz interakcyjny związany z życiem Skinnera i jego późniejszymi założeniami filozofii behawioryzmu, tym samym uzupełniając przyjętą $\mathrm{w}$ artykule metodę egzemplifikacji. 


\section{Koncepcja B. F. Skinnera (1904-1990)}

Gdyby sprowadzić koncepcję Skinnera do nośnych haseł czy tez, z których zasłynęła, to można by ją opisać następująco:

- warunkowanie sprawcze/instrumentalne („skrzynka Skinnera”);

- podstawowym „atomem” podlegającym badaniu jest akt zachowania (redukcjonizm);

- $\quad$ kult obiektywnego pomiaru i naukowości psychologii;

- jedyną funkcją układu nerwowego jest łączenie bodźców na wejściu z reakcjami na wyjściu (S-R);

- zachowanie jest zdeterminowane jego konsekwencjami, jest efektem warunków środowiska (determinizm);

- umysł to tylko konstrukt teoretyczny, od którego musimy się w psychologii uwolnić, pojęcie zbyteczne/czarna skrzynka;

- decydująca rola środowiska: dla przykładu wiersz jest emitowany jak światło, bez kontroli podmiotu jako reakcja na środowisko;

- miłość jest wzmocnieniem pozytywnym;

- dążenie do wolności to reakcja na awersyjne bodźce/reakcja pozwalająca pozbyć się czegoś jak kichanie czy wymioty;

- godność to efekt wzmocnień pozytywnych na reakcje pochwalane społecznie, dążenie do bycia nagradzanym;

- uczucia to tylko zachowania uczuciowe;

oraz last but not least dla tego tekstu: zbawienie w religii chrześcijańskiej to odroczona na całe życie nagroda. W dalszej części zajmiemy się właśnie aspektem (anty)duchowości obecnej w koncepcji tego wybitnego behawiorysty, ale zanim do tego dojdziemy, wprowadzimy w pojęcie duchowości i psychologii zajmującej się tą sferą.

\section{Psychologia duchowości}

Zgodnie z najprostszym podziałem sfer uczenia się, a szerzej aktywności człowieka, istnieje w nas sześć zhierarchizowanych sfer umysłowych, zaczynając od środowiska (kontekst, otoczenie, ludzie), poprzez zachowania, umiejętności i zdolności, dalej przekonania i wartości, inaczej przedmiot naszej wiary oraz tożsamość, czyli poczucie siebie i swej misji oraz poziom ostatni, najwyższy - poziom duchowy, odnoszący ludzi poza ich samych. Naturalną też tego konsekwencją jest popadanie w obszar „in-between”, obszar „w-pomiędzy” Bogiem a nicością, obszar, w którym odbywa się najczęściej odczuwana egzystencja człowieka. Obszar, w którym bywa człowiek i tworzy swą płynną, migotliwą tożsamość. Niewykluczone, że duchowość to także konieczny wymiar dla człowieka starającego się nie tracić w całym tym zgiełku rozumu, punkt odniesienia, odczuwane/istniejące/usensowniające „Coś/Ktoś więcej”, czy inaczej „nie-ludzki Inny”. 
Psychologia jako tradycyjnie nauka o duszy posiada, licząc choćby od czasów Williama Jamesa Doświadczeń religijnych (James 2001) i Wilhelma Wundta Voelkerpsychologie (Schneider 2008), tradycję tropienia tej sfery życia - sfery duchowej, traktowanej z perspektywy tej nauki jako sfera życia psychicznego, precyzyjniej: wyższych procesów umysłowych. To tutaj, niestety częściowo redukcjonistycznie rozumiany, typowo ludzki produkt czy zdobycz istoty ludzkiej, specyficzny dla jej typu umysłowości. Stąd człowieka opisuje się jako homo symbolicum, homo myticus, wreszcie homo religiosus - byt skazany na funkcję symboliczną, na tworzenie i pławienie się w kulturze symbolicznej, np. mitach, mający (z konieczności?) upodobanie $\mathrm{w}$ konfrontacji ze sferą duchową. Sferą, która stanowi podstawową wartość człowieka, sferę, którą można zatem nazwać życiem. Życie (duchowe) należy w tym rozumieniu traktować jako realność każdego człowieka, uczestnika i twórcy dowolnej kultury, a także podstawową jego wartość. Tą sferą zajmuje się psychologia noetyczna, inaczej psychologia duchowości.

American Psychological Association (zrzeszający dziesiątki tysięcy psychologów, autorytatywny odpowiednik Polskiego Towarzystwa Psychologicznego) uznaje „duchowość" (spirituality) za jedną z pięciu dziedzin problematyki wellbeing (dobre samopoczucie, dobrostan). Patrząc na „duchowość” od tej - „niepragmatycznej” - strony, trzeba wspomnieć o jej najbardziej oczywistym, jak sądzi wielu, wyrazie: religijności. Analiza słownikowa i analiza literatury naukowej, w której występuje termin „duchowość” lub słowa bliskoznaczne (np. „duchowy”), ukazuje bliskość znaczeniową tego terminu i pojęcia religijności lub religijnej dojrzałości. Niezależnie od tego, termin „duchowość” jest wyjątkowo wieloznaczny, utożsamia pojęcie duchowości z życiem religijnym, a szczególnie z jego przejawami w postaci religijnych medytacji, ascezy, modlitwy i innych praktyk pobożnych, zwłaszcza w obrębie reguł zakonnych. Nie znaczy to oczywiście, że duchowość nie ma nic wspólnego z religijnością. Przeciwnie, w pewnym sensie religijność jest najpewniejszą z wypracowanych we wszystkich kulturach i społeczeństwach drogą duchowej ekspresji i rozwoju duchowego. Dzieje się tak przede wszystkim dlatego, że religie są „pigułkami” o charakterze panaceum, pomagającymi większości - przekonanych o ich skuteczności - ludzi. Duchowość jest tylko - i aż - przejawem typowej psychicznej działalności, zdobyczą jednostki ludzkiej, jak żadna inna istota postawionej przed egzystencjalnym dylematem. W tym sensie, duchowość jest differentia specifica człowieka, zaś produktem życia duchowego jest szeroko rozumiana kultura, $\mathrm{w}$ tym religia.

\section{Psychobiografia B. F. Skinnera: presja i porzucenie wiary}

W swojej trzyczęściowej autobiografii Skinner wielokrotnie podkreślał, jaką krzywdę wyrządziła mu religia (w rodzinie protestanckiej) i jaką skazę pozostawiła w jego osobowości (Skinner 1977, 1979, 1983; Bjork 1997). Pierwszym religijnym 
doświadczeniem, jakie mu zafundowano, była historia o karaniu dzieci w piekle, opowiedziana mu przez babcię:

Pierwsze religijne nauczanie, które pamiętam, zostało mi wpojone przez moją babcię, Josephine. Pragnęła, bym nigdy nie kłamał, a swoje prośby wzmacniała opowieściami o karaniu za kłamstwa. Pamiętam, jak pokazywała mi kominek z rozżarzonymi węgielkami mówiąc, że dzieci, które kłamią, są po śmierci wrzucane do takiego miejsca (Skinner 1977: 60).

Skinner długo przeżywał opowieść Josephine. Dodaje, że przez wzgląd na tę historię każda, nawet najmniejsza popełniona przez niego nieuczciwość, sprawiała mu katusze:

Niedługo po tym, miałem chyba z sześć lat, sąsiad zapytał mnie, czy pewien mężczyzna jest moim wujkiem i odpowiedziałem, że tak. Później dowiedziałem się, że był moim przyszywanym wujkiem. Zdałem sobie sprawę, że skłamałem sąsiadowi. To może być absurdalne, ale ja naprawdę doświadczałem wtedy niewyobrażalnego poczucia winy (tamże).

Wychowanie religijne w protestanckiej rodzinie Skinnera polegało głównie na straszeniu konsekwencjami, które spotykały człowieka czyniącego zło. Przykładem presji środowiska, jakiej podlegał Skinner, było również wychowanie jego rodziców:

Jakiś czas później wybrałem się na występ magika. Finałowym punktem występu było pojawienie się diabła. Byłem przerażony. Spytałem ojca, czy diabeł tak po prostu wrzucał małych chłopców do Piekła, a ojciec zapewnił mnie, że właśnie tak było (...). Wciąż przypominam sobie, jaki żal, skruchę i przerażenie czuło wtedy moje młodzieńcze serce... (tamże).

Wspomnienie to było dla Skinnera uciążliwe, co widać po wielości powtórzeń zawartych w jego autobiografii. Konsekwencje surowego religijnego treningu trwały długo i przynosiły swoje owoce latami. W wieku nastoletnim behawiorysta był pod jego ciągłym wpływem:

Kiedy miałem trzynaście lat, w sklepie na wyprzedaży w Binghantom pojawiły się peryskopy (...). Wziąłem jeden z nich i przez pomyłkę wcisnąłem zatyczkę skierowaną w moją stronę. Z zewnątrz wyszło niewielkie lusterko, którego nie mogłem włożyć z powrotem do środka. Bałem się powiedzieć o tym rodzicom a sam nie miałem pieniędzy, więc odłożyłem peryskop na miejsce i uciekłem. Poczucie winy prześladowało mnie dniami i nocami (tamże: 62). 
Nawet niewielkie błędy sprawiały, że samopoczucie Skinnera obniżało się, wpędzając go w poczucie winy, dotyczyło to nie tylko bliskich przyszłego psychologa, ale też obcych mu osób:

Kiedyś tata przyprowadził na kolację naszego lokalnego polityka. Jak tylko pojawiała się okazja do zachwycenia go jakąś odpowiedzią na zadawane pytanie, wykorzystywałem ją. Spytał, czy kiedyś byłem w Waszyngtonie, a ja odpowiedziałem, że nie, nigdy nie byliśmy. Wiem, że „byliśmy” nie było prawidłową odpowiedzią, ale nie poprawiłem się i to niewielkie przejęzyczenie prześladowało mnie bardzo długo (tamże).

Przykład ten wskazuje na rodzącą się w Skinnerze skłonność do neurotycznego zamartwiania się. Niedługo po tych wydarzeniach mógł odczuć pewną ulgę, związaną z nauczaniem w liceum. Częścią jego religijnego treningu stała się znajomość z panną Graves, nauczycielką plastyki: „Panna Graves była liberałem, ona jako pierwsza powiedziała nam, że opowieści przedstawione w Biblii mogą być metaforami (...). Zanim ostatecznie zaakceptowałem swoją niewiarę, byłem rozdarty pomiędzy ateizmem a tradycją" (tamże: 61).

Panna Graves obudziła w Skinnerze ciekawość dotyczącą jego własnej wiary oraz jej powolnego zachwiania się. Tuż po naukach panny Graves, ważną częścią religijnego treningu, o którym wspomina Skinner, było natknięcie się na Quo Vadis Sienkiewicza w szkolnej bibliotece:

Sienkiewicz, co nie ulega wątpliwościom, chciał udowodnić, że założenia chrześcijaństwa stanowią niepodważalną prawdę. Jednak jego książka nie zdołała podeprzeć jego tezy (...). Admirowałem Petroniusza, zgadzając się z nim. Któregoś razu, mijając pannę Graves na korytarzu, powiedziałem, że już nie wierzę w Boga. Powiedziała mi, że też przez to przechodziła (tamże: 112).

Skinner powoli dochodził do wniosku, że ślepa wiara w tradycję nie sprzyja naukowemu rozwojowi. W tymże naukowym rozwoju Skinnera brał również udział profesor Bowles, z którym Skinner rozmawiał o wierze:

Jak moi rodzice, podejrzewał pewnie, że powoli stawałem się agnostykiem, o ile nie ateistą i pożyczył mi książkę God or Gorilla [„Bóg czy goryl” - przyp. autora], która wyśmiewała paleontologię i dotychczasowe starania dążące do odtworzenia anatomii wczesnego człowieka z zębów albo kawałka szczęki (tamże: 147).

Przytoczona przez Skinnera opowieść sugeruje, że próbowano powstrzymać go przed utratą wiary na różne sposoby, jednak on był już daleko na swojej ateistycznej drodze. Ostatecznie podejście Skinnera do religii ugruntowała śmierć jego brata 
mająca miejsce podczas świąt wielkanocnych. Opis tego wydarzenia zawarł Skinner w swojej autobiografii:

Bolała go głowa, wziął kilka tabletek aspiryny. Płakał, byśmy wezwali doktora, był przerażony (...). Zemdlał, a resztki jedzenia wypływały $\mathrm{z}$ jego ust, chociaż nie wymiotował sam z siebie. Gdy przyjechał lekarz, spytałem go, czy mam wezwać rodziców, powiedział, że tak. (...) Weszliśmy do domu, by zastać doktora zajmującego się ciałem Ebbiego. To prawda, umarł (tamże: 208).

Śmierć szesnastolatka wstrząsnęła całą rodziną, jednak to Frederick był osobą, która zachowała spokój mimo otaczających go warunków. Jego chłodne, logistyczne podejście podczas opisywania sytuacji, która przytrafiła się Edwardowi, pozwoliło ratownikom zrozumieć, że chłopak nie umarł przez zatrucie pokarmowe, jak uprzednio stwierdził lokalny lekarz, a udar:

Lekarze wykonujący autopsję pytali mnie o symptomy i opisałem im, pośród innych dolegliwości, dziwny sposób, w jaki wymiotował mój brat - nie kaszlał ani nie spinał się. Powiedzieli ojcu, że moja obiektywność bardzo im pomogła. Z takim samym podejściem patrzyłem na moich rodziców, którzy dowiedzieli się, że mój brat nie żyje (tamże: 210).

W tamtym czasie Skinner zrozumiał, że jakakolwiek emocjonalność może przeszkadzać w określaniu faktycznego stanu człowieka, tym samym fascynując się opisem ludzkich zachowań bez założenia mentalizmu. Po śmierci brata Skinner udał się na studia, by uciec od rodziców i obowiązku bycia chłopcem rodziny: „Nigdy nie chciałem takiego stanowiska, a w przyszłości miało się ono stać niezwykle problematyczne" (tamże). Początkowo studiował literaturę, jednak nie dawało mu to takiej satysfakcji, jaką chciał osiągnąć, zdobywając wiedzę. Nadal fascynowało go ludzkie zachowanie oraz wynalazki. Czego nie należy pominąć w autobiografii Skinnera, to wspomnień o jego wewnętrznej samotności, związanej z porzuceniem wiary. Życie społeczne Skinnera było ograniczone do rutyny, jaką sobie narzucił. Nie miał zbyt wielu kontaktów z przyjaciółmi ani kobietami. „Pamiętam, jak przechadzałem się ulicami, czując fizyczny ból, ponieważ nie miałem kogo objąć. Poezja mi pomogła" (tamże: 207). W wieku dwudziestu kilku lat Skinner zaczął się głęboko zastanawiać nad utratą własnej wiary przy dokuczających mu problemach zdrowotnych, m.in. tachykardii:

Wciąż czytałem Biblię, podobały mi się niektóre hymny (...). Rozmawiałem z niektórymi studentami na tematy wiary. (...). Bugsy Morrill, uczony, którego szanowałem, uczył w szkółce niedzielnej! Nie czując się z tym dobrze, udałem się do Billa Squiresa, który głosił pompatyczne poranne kazania i trzęsącym się głosem wyjawiłem mu, że nie wierzę w Boga. Niewiele mi pomógł (tamże: 220). 
Wydaje się, że Skinner został zupełnie sam ze swoimi doświadczeniami i to mógł być powód odczuwanej przez niego pustki. Na studiach nauka stopniowo zaczęła wypełniać tę pustkę. Na ścieżkę behawioryzmu skierował Skinnera filozof Bertrand Russell, który

odwoływał się do teorii Watsona, chwaląc jego odkrycia. (...). Zacząłem gromadzić własną biblioteczkę, wśród której pozycji znalazł się Behawioryzm Johna Watsona, Filozofia Bertranda Russella, Conditioned Reflexes Iwana Pietrowicza Pawłowa, książki, które, jak myślałem, przygotowywały mnie do kakiery psychologicznej (Skinner 1979: 4).

Behawioryzm podążał za punktem widzenia Skinnera. Był „zachwycony tą nauką” (tamże: 44), a także „przekonany, że koncept związany z reakcjami na bodźce obejmował całe pole psychologii" (tamże: 70). Sądził także, że nauka może prościej wyjaśnić to, co dotychczas komplikował mentalizm czy religia. „Wysłałem do moich rodziców list wyjaśniający, że dusza była starszym określeniem umysłu" (tamże: 75).

Skinner, po ukończeniu studiów, dostał się do szkoły doktorskiej i odnosił ogromne sukcesy naukowe. Behawioryzm był dla badacza ucieczką od samotności, a nawet pewnej niestabilności emocjonalnej. Przykładem tego jest jego zachowanie po rozstaniu się z jego studencką miłością, Neddą (Ruth Cook), która porzuciła Fredericka dla innego, chronicznie chorego, mężczyzny, z którym była zaręczona. Skinner wspomina, że "Jakkolwiek nie byłaby to racjonalna decyzja, bardzo mnie uderzyła (...). Pewnego dnia chwyciłem za drut, zgiąłem go w kształcie litery N, podgrzałem go i przytknąłem do lewego ramienia" (tamże: 137).

Lata później Skinner napisał: „Miłość to obopólna tendencja dwóch jednostek do wzajemnego wzmacniania, gdzie wzmocnienie może, ale nie musi być seksualne" (Skinner 1953: 310). Jako że behawioryzm nie badał emocji, lecz zachowania, był ucieczką przed tym, co wewnętrzne. Biorąc pod uwagę skłonność do zachowań neurotycznych, takich jak m.in. zarozumiałość, drażliwość, upartość, niepokój; czy do zachowań niestabilnych, takich jak m.in. wybuchowość, impulsywność i wysoka aktywność; a także zachowań antyspołecznych, m.in. sztywność, nietowarzyskość czy refleksyjność, można postawić następującą hipotezę: Skinner był osobą neurotyczno-ekstrawertyczną. Wpływ na tę okoliczność miało z pewnością wychowanie w sztywnym środowisku, ale też ciągła kontrola ze strony jego matki, Grace. „Zarozumiałość zawsze była problemem mojego ojca. Zdaje się, że wieczna kontrola mojej matki dosięgła również i mnie" (Skinner 1979: 139). Skinner identyfikował się z ojcem przez jakiś czas, dzieląc z nim fizyczne i psychiczne frustracje. Dowodem na to były liczne problemy zdrowotne związane z otrzymywaną krytyką dotyczącą założeń behawioryzmu, którą niezwykle się przejmował: „Pojawiały się symptomy fizjologiczne (...), niestrawność, dwa lub trzy razy w tygodniu (...). To był ten rodzaj symptomów, które nazwano psychosomatycznymi, a określenia tego, jako behawiorysta, nie znosiłem" (tamże: 140). 
Skinner radził sobie z tymi problemami zupełnie sam, zamykając się w swojej pracowni. Dzięki kolejnym wynalazkom zapominał o towarzyszącym mu bólu.

Będąc już doktorem na Uniwersytecie Harvardzkim, Skinner ożenił się z Yvonne Blue, miał z nią dwójkę dzieci - Julie oraz Debbie. Wierząc nade wszystko w zasadność behawioryzmu, stosował warunkowanie również w ich wychowywaniu. Dotyczyło to również podejścia do religii - nie chciał, by była przymusem, oszczędzając im tego, co sam przeżywał (Skinner 1983): „Cierpiałem przez religijną edukację moich rodziców i mojej babci, a Yvonne miała podobne doświadczenia. (...) W przeciągu dwóch albo trzech lat, gdy Julie dowiedziała się, że na szkółkę niedzielną trzeba chodzić, straciła zainteresowanie" (Skinner 1979: 278).

Skinner podkreślał, że $\mathrm{w}$ wychowaniu nie powinny być stosowane kary, lecz wzmocnienia pozytywne - powinno się zauważać to, co człowiek robi dobrze, by nie dopuścić do popełniania przez niego błędów. „Mądrzy rodzice uczą się, że lepiej jest raczej nagradzać dziecko za dobre zachowanie niż karać je za złe" (Skinner 1978: 55). W swoich książkach i artykułach pisał, że chce przekształcić psychologię w naukę o zachowaniu, wyzbywając się niepotrzebnego mentalizmu, który obciążał psychologię w znacznym stopniu (Skinner 1953). „To, co czujemy lub obserwujemy na drodze introspekcji, nie jest żadnym fizycznym światem świadomości, umysłu czy życia umysłowego, ale własnym ciałem obserwatora" (Skinner 2013: 36). Zależało mu przede wszystkim na obiektywizmie, by w badaniach nie dochodziło do mentalistycznych nadużyć czy domysłów albo wpisywania działań Boga w coś, co było naturalne: „Niezdolni pojąć czyjegoś zachowania, przypisujemy je komuś, kogo nie możemy zobaczyć (...). Pojęcie jaźni pozwala wyjaśnić motywy i na tym kończą się dociekania" (Skinner 1978: 36).

Wyjaśniając przyczyny zachowania, podkreślał, że wszystko to, co dotyczy człowieka, jest związane z jego wyposażeniem genetycznym oraz środowiskiem: „Środowisko nie tylko dopinguje czy pobudza, ono selekcjonuje” (tamże: 40).

Skinner uznał, że skoro od początku do końca życia jesteśmy poddani nieustannej kontroli, nie możemy mówić o wolnej woli i godności człowieka tak, jak dotychczas pojmowała to literatura:

Walka człowieka o wolność nie jest spowodowana umiłowaniem wolności, jest po prostu swego rodzaju reakcją behawioralną, charakterystyczną dla ludzkiego organizmu, a polegającą głównie na unikaniu lub ucieczce od tak zwanych awersyjnych cech środowiska. (...) Pojęcie wolności powstało w wyniku awersyjnych następstw zachowania, a pojęcie godności związane jest ze wzmocnieniem pozytywnym (tamże: 64-65).

Religia (Skinner 1978) działała dzięki wzmocnieniom - zarówno pozytywnym, jak i negatywnym. Przez lata zmieniały się tylko formy jego działania. „Kościół odwraca się od groźby ognia piekielnego, podkreślając miłość bożą. (...) To, co laik nazwie wynagrodzeniem, jest wzmocnieniem pozytywnym" (tamże: 55). Człowiek 
był według Skinnera moralny, jeśli żył w moralnej kulturze - nikt nie posiadał moralności obiektywnej, ponieważ prawa były kreowane przez ludzi i dla ludzi. Skinner wielokrotnie odnosił się do wolności człowieka, którą osiąga się dzięki prostym formom zachowania. Według niego pojęcie wolności „powstało w wyniku awersyjnych następstw zachowania" (tamże: 65). Ludzie uciekali przed karą, zatem sformułowali pojęcie pozwalające im usprawiedliwić własne zachowania. Skinner był świadomy tego, że trudno będzie bronić technologii zachowania, skoro zagraża ona ukrytym wartościom docenianym przez ludzi. Łatwiej jest bowiem myśleć, że robi się coś dla kogoś z dobroci serca, a nie dlatego, że nagrodą za działanie jest wzmocnienie pozytywne w postaci dobrego samopoczucia. „Uczucia są produktami ubocznymi i nie powinno się ich mylić z przyczynami" (tamże: 38).

Skinner do końca życia trzymał się swoich poglądów, dokumentując je własnymi odkryciami naukowymi i filozofią behawioryzmu. Cenił uczucie wolności, ale znał też jej iluzję. Kontrola, którą sprawowała nad całym domem jego matka, zapewniła go o braku wolnej woli. Opowieści babci i ojca o istotach i ludziach każących piekłem za złe uczynki zapewniły go o braku godności. Doświadczenia, jakie obserwował w laboratorium oraz na co dzień upewniły go, że nie można mówić o ludzkiej autonomii. Do końca życia pozostał ateistą. „Wierzenia religijne legły u podstaw pięknej architektury, muzyki, malarstwa, rzeźby, prozy i poezji" (Skinner 1987: 14). Niepokojąc się o kondycję współczesnego świata, proponował swoje rozwiązania m.in. w utopijnej powieści Walden Two czy filozoficznym eseju Poza wolnościq i godnościq, jednak zostały one uznane za utopijne lub totalitarne i przysporzyły mu wielu wrogów, m.in. takich jak pisarz Joseph Wood Krutch (1953), psychiatra Tomasz Szasz (1974) czy filozof Ayn Rand (1982).

\section{Wiara w wolną wolę i atak na myśl (i osobę) Skinnera}

Christopher Hitchens pisał w swojej książce Śmiertelność, że pod koniec życia otrzymywał rozmaite listy z pogróżkami. Pisano, że zasłużenie cierpi na raka krtani, ponieważ nie wierzy w Boga lub neguje wiarę, walcząc z Kościołem (Hitchens 2012). Podobna nienawiść skierowana w stronę Skinnera wynikać mogła z niezgody, ale też z przyzwyczajenia do własnych przekonań związanych z wiarą w Boga - lub w wolną wolę, godność i autonomię człowieka.

\section{Joseph Wood Krutch: Skinner uczynił Boga z nauki}

Pierwszym przykładem agresji ukrytej pod przekonaniami jest dzieło Josepha Wooda Krutcha (1953). To, że był osobą wierzącą w Boga podkreśla on sam na łamach The Measure of Men: on freedom, human values, survival, and the modern temper. W książce tej Krutch odniósł się negatywnie do całego konceptu Walden 
Two, porównując go do komunistycznych i nazistowskich idei związanych z odbieraniem ludziom wolności:

Człowiek, na którym takie eksperymenty są przeprowadzane, jest niczym innym, jak tylko plastikowym produktem zewnętrznych procesów działających ponad nim (...). Jego pragnienia, żądania, przekonania i ideały są dokładnie tym, czego życzy sobie eksperymentator. (...) Jego szczęście jest zależne od inżyniera, który do tego szczęścia doprowadził (Krutch 1953: 61-62).

Krutch uznał, że Skinner podjął się wybitnej próby manipulacji, próbując pozbawić świat Boga i zastępując go Naturą lub nauką. Co więcej, krytyk uznał, że Skinner uczynił Boga z nauki - „Społeczność taka jak Walden Two, może poza znajdującą się tam garstką neurotyków kultywującą własne obsesje i czczącą mrocznych bogów, mogłaby podobać się komuś, kto całkowicie zatracił swoje wnętrze" (Krutch 1953: 247).

W tym momencie należałoby odwołać się do filozofii chrześcijańskiej, ponieważ w tym nurcie mieściły się przekonania Krutcha. Behawioryzm mógł odciągać człowieka od odpowiedzialności tak samo, jak wiara w wolną wolę. Dowiodły tego badania Cory'ego Clarka i wsp. (2014): świadomość posiadania wolnej woli sprawia, że człowiek nie żałuje skazańców, ponieważ uważa, że postępowali oni świadomie. Sam Harris (2012) podaje przykład przestępców, którzy w sposób okrutny zamordowali pewną amerykańską rodzinę i zostali skazani - tymczasem po latach badania wykazały, że odpowiedzialny za ich zachowanie był guz mózgu, a nie ich wola. Neurobiolog dodaje, że jesteśmy kompilacją genów, środowisk, temperamentów - i nie na wszystko mamy wpływ, tak jak nam się początkowo wydawało. Skinner, broniąc swoich tez w artykule Freedom and the Control of Men (1955) pisał: „Jesteśmy kontrolowani przez świat, w którym żyjemy - który był i będzie konstruowany przez człowieka. Pozostaje pytanie: czy mamy być kontrolowani przez przypadki, tyranów, czy nas samych, dzięki intelektualnemu tworzeniu kultury?" (Skinner 1955: 56). Odpowiedź na to pytanie była według Skinnera oczywista - jesteśmy kontrolowani przez środowisko, ale możemy je też kontrolować (tamże: 1961).

\section{Tomasz Szasz: behawioryzm jest religią Skinnera}

Kilkanaście lat później ortodoksyjnego behawiorystę ostro skrytykował psychiatra Tomasz Szasz (1974). Jego argumenty były równie emocjonalne co Krutcha (1953). Należy jednak przy tym podkreślić, że Szasz był częściowo uwikłany pomiędzy wiarę a niewiarę, chociaż sam określał siebie ateistą. Nie przeszkodziło mu to jednak na sprzeciwianie się psychiatrii i jej spojrzeniu na choroby psychiczne tak, 
jak robiła to religia. Psychiatria stała się jego zdaniem nową religią, a nauka - wcześniej negowaną magią (Szasz 1961). Na kilka lat przed odebraniem sobie życia psychiatra poczynił artykuł, w którym rozważał usprawiedliwianie przymusu poprzez religię i psychiatrię (Szasz 1987). Wspomnienie o tym jest o tyle ważne, że Szasz nie krytykował Skinnera ze względu na przywiązanie do wiary, a do własnych poglądów. Walczył o prawo do samobójstwa, udowadniając tym samym, jak ważne jest dla niego istnienie wolnej woli. (Mimo to sprzeciwiał się eutanazji - dostrzec można zatem pewną rozbieżność jego poglądów). Uważał on, że tym, co odróżniało człowieka od zwierzęcia, była celowość istnienia. Sądził, że Skinner odbiera ludziom tę celowość i niszczy ją tak, jak ludzki język, tworząc własną mowę (Skinnerese) i pozbawiając ludzkość sensu. Szasz był również przeciwny założeniu, jakoby człowiek był obiektem kontrolowanym: „Istoty ludzkie nie mogą żyć bez znaczenia; tworzą lub niszczą znaczenie, właśnie kimś takim jest w mojej opinii Skinner - lub próbuje być - jednym z największych niszczycieli znaczenia, a więc człowieka" (Szasz 1974: 7). Dla Szasza Skinner bawił się w Boga, pozbawiając człowieka zarówno celowości, jak i godności i wolnej woli. Skonstruował świat niewolników bez panów, moralność bez etyki i człowieka bez języka. Najmocniejszym stwierdzeniem użytym przez Szasza było nazwanie Skinnera mordercą i porównanie go do masowych morderców, którzy fascynują się odbieraniem wolności i życia swoim ofiarom (Szasz 1974). Niezwykłe wzburzenie, jakie wzięło kontrolę nad pozostałymi emocjami krytyka, doprowadziło do stworzenia niezwykle niepochlebnej recenzji, która wpłynęła na negatywne postrzeganie behawioryzmu przez społeczeństwo współczesnej Ameryki i nie tylko. Sam Szasz przyznaje otwarcie „nie lubię Skinnera. (...) Skoro niezdrowe uczucia nie istnieją, jak wyjaśnia Skinner, uważam go za warunkującego mnie negatywnie" (tamże: 6). Ostatecznie Szasz uznaje Skinnera za osobę czyniącą z innych ludzi obiekty i porównującą ich do zwierząt, jakoby nie mieli wolnej woli i świadomości. W ujęciu Szasza ortodoksyjny behawiorysta był niszczycielem znaczenia, a więc człowieka. Co więcej, nie odwoływał się do źródeł albo je negował - tak jak negował istnienie wolnej woli czy ludzkiej godności.

Skinner wiele razy odpierał założenie, jakoby behawioryzm ignorował świadomość, uczucia i stany umysłu (Skinner 1977, 1978). Zaprzeczał także, jakoby nauka ta jako pierwsza dokonywała dehumanizacji człowieka:

Respektując niektóre metody kontroli (na przykład przymus), nie potrzeba technologii zachowania, ponieważ technice tej społeczeństwo się sprzeciwia. Są zachowania nazwane złymi, nielegalnymi i grzesznymi. Ale użyć metody inżynierii zachowania, ukryto ich prawdziwą naturę, przykładem tego niech będą edukacja, dyskusje nad moralnością czy perswazja (Skinner 1955: 54).

Nawet jeśli zachowaniem człowieka rządziły pewne prawa, to nie oznaczało, że będzie można go porównać do maszyny: maszyny nadal rządzą się własnymi 
prawami (Skinner 1978). Człowiek przejawiał zachowania, jednak nie były one wyłącznie ludzkie - to samo dotyczyło zwierząt. Udowodnił to Koichi Ono (1978) w swoim badaniu - potwierdzając zależność magiczną występującą nie tylko u zwierząt (Skinner 1948), ale też u ludzi.

\section{Ayn Rand: Skinner stawia się na miejscu Boga}

Krytyki dotyczącej stawiania się na miejscu Boga dostąpił Skinner również od Rand (1982). Należy wspomnieć, że Rand była przedstawicielką obiektywizmu (w nurcie tym rzeczywistość istnieje niezależnie od świadomości, a dążenie człowieka do szczęścia jest jego powodem do życia), sprzeciwiała się jakimkolwiek formom mistycyzmu, w tym religii, jednak wierzyła, że wolna wola jest jednym z podstawowych praw autonomicznego człowieka - było to przekonanie, w opozycji do którego stał Skinner. W swoim eseju The Stimulus and the Response filozof odniosła się do dzieła Skinnera (1978), porównując jego książkę do Frankensteina idącego na wojnę z Człowiekiem Autonomicznym: „Książka sama w sobie jest niczym wcielenie Borisa Karloffa w potwora, Frankensteina (...). Wydźwięk książki, zupełnie jak Karloffa, jest artykułowaniem niezrozumiałych warknięć w stronę największego wroga - Człowieka Autonomicznego" (Rand 1982: 166-167).

Skinner, według Rand, zamienił kulturę i Boga miejscami. Celem kultury było przetrwanie bez względu na wszystko. Filozof porównała rozmyślania ortodoksyjnego behawiorysty do praktyki Adolfa Hitlera, który również warunkował swoich wyznawców, wymagając ofiar służących przetrwaniu imperium nazistowskiego - tym samym budowaniu kultury Niemiec: „Jeśli przetrwanie jest jedyną wartością, dla której kultura ma się poświęcać i według której dana kultura ma być sądzona, w takim razie kultura Nazistów, która trwała dwanaście lat, też miała własną wartość (...)” (tamże: 178).

Skinner, jak podsumowała Rand, dążył do tego, by człowieka zniszczyć, zdeptać i w ostateczności na niego splunąć, odbierając mu wszystko to, co było dla niego ważne - wolną wolę, autonomię i godność:

Motywem przewodnim tej książki jest nienawiść skierowana w stronę umysłu i podstawowych wartości człowieka (...). Zniszczyć Człowieka Autonomicznego - napaść na niego, uderzyć, zranić, a jeśli to zawiedzie, to splunąć na niego - taki jest cel tej książki, przy czym autora nie obchodzą długofalowe, kulturowe konsekwencje, jakie to za sobą ciągnie (tamże: 182).

Z wypowiedzi Rand wypływa nienawiść do dzieła Skinnera, a może i do samego naukowca, ponieważ kobieta nie mogła się pogodzić z jego założeniami. Wiele pojęć, do których się odnosiła, traktowała bardzo osobiście - stąd emocjonalny ton 
jej wypowiedzi. Skinner, według niej, zniszczył jedyny cel życia człowieka - dążenie do szczęścia, wolność woli i autonomię.

Skinner obronił się jeszcze zanim doznał tej krytyki: „Jesteśmy kontrolowani przez świat, w którym żyjemy - który był i będzie konstruowany przez człowieka. Pozostaje pytanie: czy mamy być kontrolowani przez przypadki, tyranów, czy nas samych, dzięki intelektualnemu tworzeniu kultury?" (Skinner 1955: 56). Rozmaite kultury różnią się $\mathrm{w}$ stopniu, w jakim pomagają swoim członkom rozwiązywać problemy. Ci, którzy umieją je rozwiązywać, na pewno przeżyją:

Wydaje się czymś naturalnym, że jesteśmy skłonni do wzmacniania tych, którzy nas wzmacniają i atakowania tych, którzy nas atakują, lecz zachowanie takie jest wyzwalane przez liczne okoliczności społeczne. (...) Kredyt zaufania, jakim darzymy innych ludzi, zależy szczególnie od widzenia przyczyn ich zachowania. (...) Nie ma dla nas wartości zachowanie, które wynika ze zbyt jawnego awersyjnego nadzoru, nawet jeśli jest ono użyteczne (Skinner 1978: 66).

Uważał, że nawet jeśli ludzie walczą o wolność, to nikt nie walczy o wolność od systemu - politycznego czy religijnego. Przez lata bowiem obserwował ludzi, którzy podporządkowali się temu, co było im narzucane (Skinner 1978). Pojęcia „moralność”, „wolna wola” czy „autonomia” zostały stworzone przez człowieka, były więc częścią pewnych układów - układów, którymi można było manipulować.

Amerykańska kultura, wychowana na gruncie mitu o self-made manie była - nadal jest - bardzo przywiązana do konceptu wolnej woli, a każda próba zniszczenia jej pojęcia o tym koncepcie wiązała się z agresją skierowaną przeciwko jakiemukolwiek determiniście, w tym przeciwko Skinnerowi. Przytoczone powyżej przykłady są dowodem na to, że przywiązanie do własnej wiary oraz poglądów uniemożliwiła logiczne podejście do też przedstawianych przez behawiorystę. Zamiast tego krytyka skupiła się na emocjach, ekspresyjnych porównaniach i odrzucaniu założeń, które sprzeciwiały się istnieniu wolnej woli czy godności człowieka. Nie wszyscy krytycy Skinnera byli osobami wierzącymi w Boga, więc należy odrzucić hipotezę, jakoby wiara w Boga wpływała na agresję przeciwko ateistycznym poglądom. Udowodniono jednak, że siła przekonań dotyczących wolnej woli, godności i autonomii była w przedstawionej krytyce na tyle zauważalna, by dojrzeć stosowane w tekstach manipulacje i chwyty erystyczne. Używanie określeń takich jak „zniszczyć, splunąć czy zdeptać” (Rand 1982), „morderca” (Szasz 1974), „zabawa w Boga” (Krutch 1953) niesie ze sobą ogromny ładunek emocjonalny, wpływający na czytelnika, który nie spogląda na teksty naukowe z odpowiednią rezerwą, a odrzuca je. Krytyczne recenzje wpłynęły na negatywny odbiór behawioryzmu i samego Skinnera przez opinię publiczną. 


\section{Doświadczenie graniczne a duchowość: wiara w ewolucję a wiara w wolną wolę}

W przeciwieństwie do wymienionych krytyków, z poglądami Skinnera zgodziliby się Richard Dawkins (1996, 2007) czy Sam Harris (2012) i - pośrednio - Daniel Dennett $(1984,2003,2006)$. Są to przedstawiciele „Nowego Ateizmu” - nurtu przedstawiającego pogląd, jakoby religię należało zwalczać, stanowi ona niebezpieczeństwo dla człowieka. Ich poglądy zostaną pokrótce przedstawione $\mathrm{w}$ tabeli 1 i porównane z założeniami Skinnera.

Tabela 1. Poglądy Skinnera zestawione z poglądami Nowych Ateistów

\begin{tabular}{|c|c|c|}
\hline $\begin{array}{c}\text { Przedstawiciel } \\
\text { „Nowych Ateistów” }\end{array}$ & Poglądy & $\begin{array}{c}\text { Podobieństwa do poglądów } \\
\text { Skinnera }\end{array}$ \\
\hline $\begin{array}{l}\text { Dawkins (1996, } \\
\text { 2007); ewolucjonista; } \\
\text { ateista, antyteista }\end{array}$ & 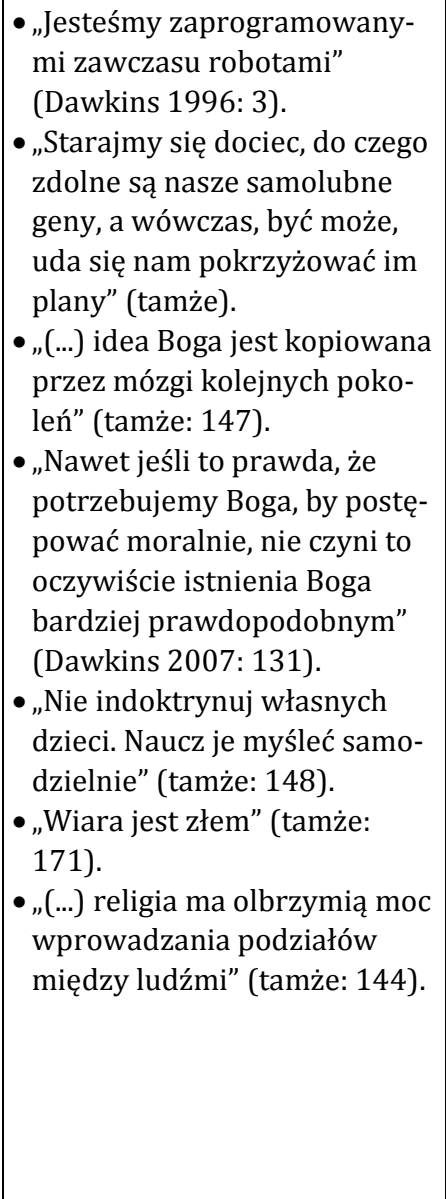 & 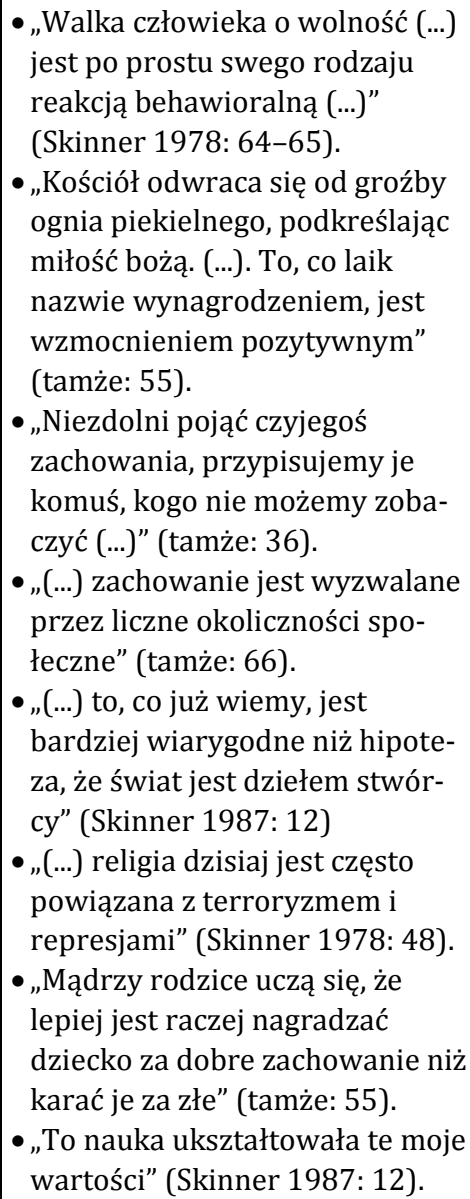 \\
\hline
\end{tabular}




\begin{tabular}{|c|c|c|}
\hline $\begin{array}{l}\text { Harris }(2004,2012) ; \\
\text { neurobiolog; ateista }\end{array}$ & $\begin{array}{l}\text { •,„Jesteśmy kombinacją genów, } \\
\text { wychowania, środowisk, idei } \\
\text { (...)” (Harris 2012: 63). } \\
\text { •,,Wolna wola jest iluzją” } \\
\text { (tamże: 6). } \\
\text { •,,Wiara w wolną wolę dała } \\
\text { nam religijną koncepcję } \\
\text { grzechu i oddała nas spra- } \\
\text { wiedliwości” (tamże: 56). } \\
\text { •,„Jesteśmy odpowiedzialni za } \\
\text { nasze postępowanie, na tyle, } \\
\text { na ile jesteśmy go świadomi” } \\
\text { (tamże: 57). } \\
\text { •,,W naprawianiu siebie } \\
\text { i społeczeństwa pracujemy } \\
\text { z naturą, nie ma nic poza nią” } \\
\text { (tamże: 74) }\end{array}$ & $\begin{array}{l}\text { •,„Środowisko nie tylko dopinguje } \\
\text { czy pobudza, ono selekcjonuje” } \\
\text { (Skinner 1978: 40). } \\
\text { • „(...) zachowanie jest wyzwalane } \\
\text { przez liczne okoliczności spo- } \\
\text { łeczne. (...)” (tamże: 66). } \\
\text { • „Pojęcie wolności powstało } \\
\text { w wyniku awersyjnych na- } \\
\text { stępstw zachowania” (tamże: } \\
\text { 64-65). } \\
\text { •„Jesteśmy kontrolowani przez } \\
\text { świat, w którym żyjemy” (Skin- } \\
\text { ner 1955: 56). }\end{array}$ \\
\hline $\begin{array}{l}\text { Dennett }(1984,2003 \text {, } \\
2006) ; \text { filozof, ateista }\end{array}$ & $\begin{array}{l}\text { • „Ludzie jako gatunek wyewo- } \\
\text { luowali (...), a razem z tym } \\
\text { ewoluowała ich kultura” } \\
\text { (Dennett 2003: 25) } \\
\text { - Odwołanie do badań Skinnera } \\
\text { (1948): ludowe wierzenia } \\
\text { powstały na zasadzie domy- } \\
\text { słów i spostrzeżeń (Dennett } \\
\text { 2006) }\end{array}$ & $\begin{array}{l}\text { •„Jesteśmy kontrolowani przez } \\
\text { świat, w którym żyjemy - który } \\
\text { był i będzie konstruowany przez } \\
\text { człowieka” (Skinner 1955: 56). } \\
\text { •ludowe wierzenia powstały na } \\
\text { bazie domysłów i spostrzeżeń } \\
\text { (Skinner 1948) }\end{array}$ \\
\hline
\end{tabular}

W tabeli 1 przedstawiono podobieństwo poglądów Skinnera, będącego ateistą, z poglądami Nowych Ateistów. Są one w większości zgodne, co do założeń dotyczących: ewolucjonizmu, braku wolnej woli, traktowania religii jako źródła wzmocnień oraz samodzielnego myślenia; wpływu środowiska oraz ewolucji i kultury na człowieka. Wiara w ewolucję jest, zwracając uwagę na podane przykłady, przeciwieństwem wiary w wolną wolę, można jedynie mówić o pozytywnym podejściu do konspektu wolnej woli (Dennett 2006), jednak nie o jej istnieniu. Wiara w ewolucję - a co za tym idzie, determinizm - jest w przypadku Skinnera oraz Nowych Ateistów przeciwieństwem wiary w Boga. Być może Dawkins, Dennett i Harris oraz Skinner stali się ateistami m.in. ze względu na rozmaite doświadczenia graniczne, mające wpływ na ich dojrzewanie, rozwój emocjonalny czy też zdobywanie wiedzy. W gronie tym można również umieścić Russella, do którego często odwoływali się Skinner, Harris czy Dawkins. Jak podaje Encyklopedia PWN (2011), cytując Karla Jaspersa: „są to krańcowe doświadczenia i przeżycia (cierpienie, śmierć, wina, walka), które ze względu na ich osobisty charakter i niemożliwość zastępstwa przez innych «rozjaśniają» ludzką egzystencję (sytuacje graniczne stawiają człowieka w prawdzie wobec samego siebie)". Oto, jak zmagali się z nimi wspomniani wcześniej uczeni. 
Russell w wieku dwóch lat stracił matkę i siostrę, w wieku czterech - ojca. Został przekazany pod opiekę babki, hrabiny Russell, razem ze starszym bratem. Jego dzieciństwo było bardzo samotne i wielokrotnie doświadczał myśli samobójczych (Pawelec 2002). W wieku piętnastu lat zaczął wątpić w zasadność wiary, ostatecznie tracąc wiarę w wolną wolę i życie po śmierci (tamże). W wieku osiemnastu lat, zapoznając się z Autobiografia Johna Stuarta Milla, porzucił argumenty popierające istnienie Boga i zaczął się określać jako ateista. Zmienił założenia zakładu Pascala, mówiąc, że jeśli Bóg jest inteligentny, doceni to, że ktoś nie jest wierzący na siłę tylko po to, by dostać się do nieba (Skinner 1987).

Skinner, doświadczając kontroli ze strony matki i religijnego treningu ze strony babci, stał się osobą neurotyczną, lękliwą, ale jednocześnie poszukującą odpowiedzi na egzystencjalne pytania (Skinner 1977). Presja religijna w domu Skinnera doprowadziła do załamania się jego wiary i wstąpienia na ścieżkę behawioryzmu (Skinner 1979). Słysząc historie o dzieciach wrzucanych do pieca za złe uczynki, młody Skinner dostąpił lęku związanego z wiarą czy istotą Boga, o czym niejednokrotnie wspomina na kartach swojej autobiografii (tamże). Późniejsze doświadczenia zdobywane w szkole i na studiach, zbieranie wyników badań i dostęp do literatury filozoficznej skonfrontowały Skinnera z jego własną niewiarą i dały mu spokój ducha (Skinner 1978). Spokój ten odnalazł w nauce, deterministycznych poglądach i behawioryzmie (Skinner 1987).

Dawkins wiarę w Boga porzucił dzięki ewolucjonizmowi (Dawkins 1996). Jest antyteistą, który stracił wiarę w Boga w młodym wieku, odzyskał ją na jakiś czas, po czym całkowicie poświęcił się ewolucjonizmowi i zanegował istnienie Boga (Dawkins 2007).

Harris wychowany był przez matkę żydówkę i ojca kwakra. W jego domu nie rozmawiało się o religii, jednak neurobiolog podkreśla, że nie został wychowany na ateistę (Harris 2004). Mimo tego, że sprzeciwia się religii, jest otwarty na doświadczenia duchowe. Książka Harrisa The End of Faith powstała pośrednio przez atak na WTC - Harris pisze w niej, że religia stanowi niebezpieczeństwo dla świata. Znalazł pocieszenie w nauce, wypełniając stratę po wierze neurobiologią (Harris 2004).

Dennett jest ateistą, nie antyteistą, posiłkuje się w swoich wypowiedziach dowodami naukowymi aniżeli docelową krytyką religii. Na jego poglądy miały wpływ studia filozoficzne (Dennett 1984). Uważa, że religia jest jak muzyka - ludzie o nią walczą, bo stanowi fundament ich przekonań. Wielu z nich bardziej „wierzy w wiarę w Boga" niż faktycznie wierzy w istnienie bóstwa (Dennett 2006). Podkreśla też, że religia powinna zostać przebadana, by sprawdzić, czy bardziej pomaga ludziom czy im szkodzi. Dennett pozostał filozofem i ateistą odnajdującym punkty wspólne w wielu wierzeniach, które opierały się na niedopowiedzeniach i domysłach (Dennett 2003, 2006).

Powyższe przykłady pokazują, że psychiczną pustkę, jak określał ją Bruce Mazlish (za: Pawelec 2002), po stracie wiary musi uzupełnić wiarą w coś innego - może to być wiara w naukę, wiara we własne poglądy czy stworzenie nowego systemu przekonań. Dennett (2006) postuluje, że wyższe wykształcenie jest związane 
z wyższą religijnością, jednak w przypadku wszystkich krytyków byłoby to założenie nieprawdziwe. Bezpieczniej jest założyć, że przekonania, które stały się podstawą wychowania lub doświadczeń granicznych, wpłynęły na pojmowanie duchowości, wolnej woli czy innych pojęć związanych z wiarą - a tego właśnie doświadczył B. F. Skinner czy bliskie jego założeniom tezy, które przestawiają Nowi Ateiści.

\section{Podsumowanie}

W artykule podjęto refleksję nad wpływem presji dotyczącej wychowania religijnego, a zanikiem wiary w wolną wolę i Boga na przykładzie B. F. Skinnera. Istotne było spojrzenie na historię dojrzewania ortodoksyjnego behawiorysty, odwołanie się do principiów środowiska protestanckiego, w którym dojrzewał B. F. Skinner. Przedstawiono krytykę dzieł Skinnera, obrazując ją jako emocjonalną odpowiedź na dysonans poznawczy w związku z preferowanymi poglądami. Porównano także krytykę dzieł Skinnera do stanowisk Nowych Ateistów: Dawkinsa (1996, 2007), Harrisa $(2004,2012)$ czy Dennetta $(1984,2003,2006)$, a także odwołano się do ich doświadczeń granicznych mających wpływ na utratę wiary. Przegląd literatury źródłowej doprowadził do następujących konkluzji:

- Czynnikami, które przyczyniły się do porzucenia wiary przez Skinnera były m.in. wychowanie, narzucona przez rodzinę Skinnerów duchowość, a także presja środowiska, w którym dojrzewał Burrhus Frederick. Prawdopodobnie to właśnie te czynniki uczyniły z niego ateistę i ostatecznie skierowały go na ścieżkę behawioryzmu.

- Siła przekonań dotyczących wolnej woli, godności i autonomii wpłynęła na agresję Krutcha, Szasza i Rand skierowaną przeciwko ateistycznym poglądom Skinnera.

- Wiara w ewolucję i determinizm jest przeciwieństwem wiary w wolną wolę. W przypadku B. F. Skinnera oraz Nowych Ateistów jest również przeciwieństwem wiary w Boga.

- Przekonania, które stały się podstawą wychowania lub doświadczeń granicznych, wpłynęły na pojmowanie duchowości, wolnej woli czy innych pojęć związanych z wiarą w przypadku zarówno Skinnera, Russella czy Nowych Ateistów.

\section{Bibliografia}

Bjork D. W. (1997) B. F. Skinner: A life, Washington, US: American Psychological Association.

Clark C. et al (2014) Free to Punish: A Motivated Account of Free Will Belief, „Journal of Personality and Social Psychology", nr 106, s. 501-13. 
Dawkins R. (1996) Samolubny gen, tłum. M. Skoneczny, Warszawa, Prószyński i S-ka.

Dawkins R. (2007) Bóg urojony, tłum. P. J. Szwajcer, Warszawa, Wydawnictwo CiS.

Dennett D. (1984) Elbow Room. The Varietes of Free Will Worth Wanting, Cambridge, MIT Press.

Dennett D. (2003) Freedom Evolves. London, Penguin Books.

Dennett D. (2006) Odczarowanie. Religia jako zjawisko naturalne, tłum. B. Stanosz, Warszawa, Państwowy Instytut Wydawniczy.

Harris S. (2004) The end of faith: Religion, terror, and the future of reason, New York, W. W. Norton \& Co.

Harris S. (2012) Free Will, Waszyngton, Free Press.

Hitchens Ch. (2012) Śmiertelność, tłum. R. Madejski, Katowice, Sonia Draga.

James J. (2001) Doświadczenia religijne, tłum. J. Henpel, Warszawa, Nomos.

Krutch Wood J. (1953) The Measure of Men: on freedom, human values, survival, and the modern temper, Washington, Peter Smith Pub Inc.

Ono K. (1987) Superstitious behavior in humans, „Journal of the Experimental Analysis of Behavior", nr 47 (3), s. 261-271.

Pawelec T. (2002) Psyche i Klio. Historia w oczach psychohistoryków, Lublin, Wydawnictwo Uniwersytetu Marii Curie-Skłodowskiej.

Piszkalski H. (1978) Problem „sytuacji granicznych” w ujęciu Karla Jaspersa, „Analecta Cracoviensia", 10. 99. 10.15633/acr.2948.

Rand A. (1982) The Stimulus and the Response w: Philosophy - Who Needs It, New York, Signet.

Runyan W. M. (1992) Historie życia a psychobiografia. Badania teorii i metody, tłum. J. Kasprzewski, Warszawa, PWN.

Schneider Ch. (2008) Wilhelm Wundt - Volkerpsychologie, Berlin, V\&R unipress $\mathrm{GmbH}$.

Skinner B. F. (1938) The Behavior of Organisms. An Experimental Analysis, New York, Appleton Century Crofts, Inc.

Skinner B. F. (1948a) 'Superstition' in the pigeon, „Journal of Experimental Psychology", nr 38 (2), s. 168-172. 
Skinner B. F. (1948b) Walden Two, Indianapolis, Hackett Publishing Company.

Skinner B. F. (1953) Science and Human Behavior, Washington, Free Press.

Skinner B. F. (1955) Freedom and the control of men w: B. F. Skinner, Cumulative Record. Definitive Edition, Great Rd City, Copley Publishing Group.

Skinner B. F. (1957) Verbal Behavior, New York, Appleton Century Crofts, Inc.

Skinner B. F. (1961) How to teach animals w: B. F. Skinner, Cumulative Record. Definitive Edition, Washington, Copley Publishing Group.

Skinner B. F. (1963) Behaviorism at Fifty w: B. F. Skinner, Cumulative Record. Definitive Edition, Washington, Copley Publishing Group.

Skinner B. F. (1977) Particulars of My Life. Part One of an Autobiography, New York, Knopf.

Skinner B. F. (1978) Poza wolnościq i godnościq, tłum. W. Szelenberger, Warszawa, Państwowy Instytut Wydawniczy.

Skinner B. F. (1979) The Shaping of a Behaviorist. Part Two of an Autobiography, New York, Knopf.

Skinner B. F. (1983) A Matter of Consequences. Part Three of an Autobiography, New York, Knopf.

Skinner B. F. (1986) Upon Further Reflection, Harlow, Pearson.

Skinner B. F. (1987) What Religion Means to Me?, „Free Inquiry”, nr 7, s. 12-14.

Skinner B. F. (1990) Can Psychology Be a Science of Mind?, „American Psychologist”, vol. 45, nr 11, s. 1206-1210.

Skinner B. F. (1995) Zachowanie się organizmów, tłum. K. Dudziak, Warszawa, PWN.

Skinner B. F. (2013) Behawioryzm, tłum. P. Skawiński, Gdańsk, Gdańskie Wydawnictwo Psychologiczne.

Szasz T. (1974) Against behaviorism. A review of B. F. Skinner's about behaviorism, „Libertarian Review”, nr 111, s. 6-7.

Szasz T. (1987) Justifying Coercion through Religion and Psychiatry, „Journal of Humanistic Psychology", t. 7, nr 2, s. 158-174.

\section{Źródła internetowe}

Encyklopedia PWN (2011), https://encyklopedia.pwn.pl/haslo/sytuacje-graniczne; 3982244.html [dostęp: 29.04.2020]. 